\title{
UNIVERSITYOF
}

FORWARD

THINKING

WESTMINSTER用

WestminsterResearch

http://www.westminster.ac.uk/westminsterresearch

An exploratory study of how a Korean chaebol's learning culture facilitates customer service

Lee, Yang-im and Trim, P.R.J.

This is an Accepted Manuscript of an article published by Taylor \& Francis in the Journal of Global Scholars of Marketing Science, 25 (4), pp. 338-357. The final definitive version is available online:

https://dx.doi.org/10.1080/21639159.2015.1073421

(c) 2015 Taylor \& Francis

The WestminsterResearch online digital archive at the University of Westminster aims to make the research output of the University available to a wider audience. Copyright and Moral Rights remain with the authors and/or copyright owners.

Whilst further distribution of specific materials from within this archive is forbidden, you may freely distribute the URL of WestminsterResearch: ((http://westminsterresearch.wmin.ac.uk/)).

In case of abuse or copyright appearing without permission e-mail repository@westminster.ac.uk 


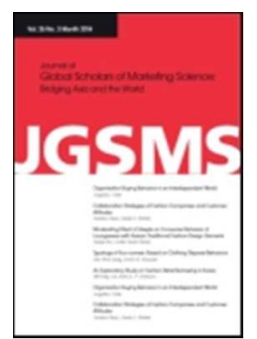

\section{An exploratory study of how a Korean chaebol's learning culture facilitates customer service}

\begin{tabular}{|r|l|}
\hline Journal: & Journal of Global Scholars of Marketing Science \\
\hline Manuscript ID: & RGAM-2015-0007.R2 \\
\hline Manuscript Type: & Original Article \\
\hline Keywords: & $\begin{array}{l}\text { Culture, local knowledge, marketing strategy, business performance, } \\
\text { Global marketing }\end{array}$ \\
\hline \multicolumn{2}{|l}{} \\
\hline
\end{tabular}

SCHOLARONE $^{\text {M }}$

Manuscripts 


\section{An exploratory study of how a Korean chaebol's learning culture facilitates customer service.}

Dr. Yang-Im Lee, Senior Lecturer in Marketing,

Department of Marketing \& Business Strategy, Westminster Business School

University of Westminster, 35 Marylebone Road, London NW1 5LS.

UK.

E-mail: y.lee@westminster.ac.uk

Telephone: 02079115000 ext. 66893

*Dr. Peter R.J. Trim, Senior Lecturer in Management, Department of Management, School of Business, Economics and Informatics, Birkbeck,

University of London, Malet Street, London. WC1E 7HX.

UK.

E-mail:p.trim@bbk.ac.uk

Telephone: 02076316764

Fax. 02076316769

* Corresponding author 


\title{
An exploratory study of how a Korean chaebol's learning culture facilitates customer service.
}

\begin{abstract}
This paper explains how the organizational learning concept is used by managers in a global Korean company to promote group work, information sharing and an open communication style in order to produce a high level of customer service. Previously collected data from a set of in-depth personal interviews undertaken with three senior managers in a Korean electronics company were analyzed and interpreted using the grounded theory approach, and a number of propositions are put forward. The research findings show that managers in a chaebol deploy organizational learning to identify skilled and knowledgeable staff, and improve the organization's capability by placing emphasis on developing harmonious, mutually oriented relationships that permeate throughout the organization. Top management demand that staff identify with government economic objectives and align the organization's strategy accordingly so that the products produced are marketable. To achieve this, the organization fosters continual interaction among managers throughout the organization's hierarchy. The chaebol's organizational learning model encapsulates a 'Corollary' (continual communication) and 'Tools' (cultural influence and relationship management), and manifests in a unique strategy that allows management systems to evolve naturally.
\end{abstract}

Keywords: Culture, Knowledge, Learning, Marketing, Service, Strategy 


\section{Introduction}

In order to achieve a high level of customer service (marketing dimension), marketing managers are placing emphasis on communication, information sharing and are assessing how the organization's overall marketing strategy (marketing dimension) facilitates a consistent service offering (Parasuraman, Zeithaml \& Berry, 1985; Jarratt \& Stiles, 2010). This is supportive of the strategic marketing approach (Aaker, 1992) and differentiation (Deshpande, Farley \& Webster, 1993), hence it can be said that strategy emerges from the marketing process itself because "serving customers better" (Baker, 1996) is about understanding the linkage between market characteristics, customer perceptions and meeting the expectations of end users. The work of Rust, Thompson, and Hamilton (2006) underpins this view and marketers are encouraged to establish a threshold (i.e., price, quality and level of service) that is acceptable to end users and various stakeholders. Product capability is central and Gonzalez-Padron, Chabowski, Hult and Ketchen (2010) have added to our understanding by explaining how shared learning (human factor) facilitates information processing and how it aids marketing strategy development (marketing dimension).

Lukas, Whitwell and Heide (2013) have explained how customer orientation provides a mechanism for restraining possible overshooting as it allows the company to identify a specific need to be satisfied. This brings to attention the capability of the employee(s) (human factor), an individual's immersion in a group (marketing department) and the behaviour of the group (human factor) that the individual belongs to. By devising and implementing a marketing strategy (marketing dimension), marketing managers have the opportunity to raise the profile of marketing staff (Drechsler, Natter \& Leeflang, 2013) and thus ensure the marketing department plays a prominent role within the organization. The work of Moon, Miller and Kim (2013) is considered informative from the perspective of raising the profile of marketing staff because it makes the case that more work needs to be done in the area of 
design innovation in marketing and especially relationship building that governs design innovation. The work of Friesl (2012) focuses on knowledge acquisition and the link with company performance builds on the work of Gonzalez-Padron, Chabowski, Hult and Ketchen (2010). Lukas, Whitwell, and Heide (2013) point out that the organization's value framework determine the company's focus and they indicate how staff within the company can formulate marketing policy that meets customer expectations. The organization's value framework also shapes relationships governing new product development capabilities and new product development performance (Yoo \& Frankwick, 2012). De Brentani and Kleinschmidt (2004) point out that senior managers need to devise appropriate organizational cultural value systems and remain committed to new product development. In addition, managers need to be openminded as adaptability is a continuous construct (Tuominen, Rajala \& Moller, 2004) and this suggests that in the case of international joint ventures/acquisitions (Anh, Baughn \& Neupert, 2006), the information communication process is influenced by cultural value systems, which are themselves the outcome of group behaviour (human factor) and organizational learning (human factor). Bearing the above points in mind, a conceptual framework has been devised from the extant literature and appears in Figure 1.

INSERT FIGURE 1 HERE

What has to be remembered about the constructs and the linkages represented in Figure 1, is that an organization's cultural value system determines how staff within an organization interact with each other and with those external to the organization. Communication plays a key role in establishing the way in which various forms of interaction manifest, and group behaviour determines how people are influenced by and in turn influence 
the organization's value system. In addition, group behaviour directly influences the organizational learning model that is in place and through teamwork, staff in the marketing department devise and implement marketing strategy, an outcome of which is the organization's customer service policy. This said, we considered it useful to build on the work undertaken to date and to provide insights into how, in an collectivist culture, the organizational learning process is linked with marketing strategy, and to explain how managers in a chaebol prioritize matters and build a relationship with the organization's customers through managing change in a pro-active manner. This we feel is a contribution to the body of existing knowledge relating to marketing strategy formulation and implementation, because it provides insights into how a set of attributes relating to marketing strategy development can be categorized and how these attributes reinforce communication and group behaviour so that the organization achieves its objectives.

This paper explains how the organizational learning concept is used to promote group work, information sharing and an open and transparent communication style in order to produce a high level of customer service (Lee \& Trim, 2014). Our research addresses two questions: (1) how do marketing staff in a chaebol utilize information in order to influence group behaviour? (2) How can the organizational learning concept be used to increase marketing knowledge in order to produce a high level of customer service? The study contributes to marketing knowledge by increasing our understanding of how organizational learning is used by marketing managers to support the marketing strategy decision-making process within a collectivist organizational culture. We add to current knowledge by focusing our effort on how the learning concept in an organization with a collectivist culture produces a high level of customer service. We build on the work undertaken by Ellemers, Sleebos, Stam and de Gilder (2013) relating to how an individual is perceived and fits into a group and we extend this to take into account how an individual is absorbed into an organizational cultural 
value system. We resonate with the work of Jarratt and Stiles (2010) who draw attention to "cultural embedded strategizing practice" and hope that the research findings will help stimulate interdisciplinary work in the area of management and marketing that will result in the development of knowledge as advocated by Yadav (2010).

\section{Methodology}

\subsection{Research Methods}

With respect to the research strategy deployed, previously collected primary data from indepth personal interviews with three senior managers based at a Korean electronics company in the UK was used as it was in the form of transcripts and had not been previously subjected to the grounded theory analytical process. Each manager had been employed by the company for over 10 years and had an extensive knowledge of the company's global marketing operations and the collectivist organizational culture that underpinned the decision-making process. The in-depth personal interview method had been used as it allowed the person conducting the interviews to probe in-depth (Patton, 1990), enter into discussion and gain further insights into the complex subject matter (Seidman, 1991).

Easterby-Smith and Thorpe (1997) suggest that qualitative research approaches are known to yield insights into management learning, hence the research strategy adopted allowed the respondents "to make knowledge claims" about how they interpreted reality, and the researcher was able to "engage in ongoing self-reflection" and pursue "an extensive and ongoing commitment to a line of theoretical research" (Suddaby, 2006, p.640). Each interview had been conducted in English, however, the researcher undertaking the data collection was fluent in Korean and did on occasion speak Korean to clarify matters.

The reason why previously collected data were analyzed and interpreted was because the research addressed the phenomenon known as strategic action (Ferlie \& McNulty, 1997). 
The previous study had addressed the topic of relationship building in the context of a partnership arrangement and had incorporated customer service and national cultural values. It was considered logical, therefore, to take the work a step further and establish how the attributes relating to marketing strategy deployment were related to a specific chaebol's organizational learning model. The three senior managers had in fact given their permission for the data to be analyzed so that insights could be gained into how a high level of customer service was produced. By analyzing and interpreting the data in the way that we did, we were able to identify themes such as organizational learning and customer service, and relate these themes back to relevant literature. The reason why the grounded theory technique was deployed was so that additional value could be derived from the existing data. One of the advantages of this was that the concepts derived from the primary data were compared with the theoretical ideas/concepts contained in relevant literature, which is representative of the inductive theory-generating research (Orton, 1997). We used the "paradigm model" put forward by Strauss and Corbin (1990) to relate themes, variables/concepts and to identify the pattern of relationships. One of the benefits of this paradigm model is that it allows researchers to think systematically about establishing causal conditions, and thus provides a basis for understanding how a set of relationships are linked. Suddaby (2006) is supportive of this approach and points out that when using the grounded theory approach, researchers need to be as transparent as possible about the methodological approach itself. A strength of the inductive research approach is that it allows researchers to add density and precision, and we recognized that our research approach provided an in-depth appreciation of how managers in a chaebol use the organizational learning concept in a culturally rich and environmentally specific context. The characteristics identified would enable us to better understand how senior marketing managers in a chaebol embrace the organizational learning concept in order to develop and implement a distinctive marketing strategy that incorporated customer service. 
With respect to the methodological approach adopted, it is important to bear in mind that the researchers were sympathetic to the view that the value of applied research is that it allows a researcher to develop their knowledge in relation to learning under specific conditions (Crossan, Maurer \& White, 2011). In addition, we considered it worthwhile to look more deeply at practical and operational issues (Sinkovics \& Penz, 2011) because by doing so, we would be able to increase our understanding of the cultural context within which the research took place.

\section{Analysis of Data and Findings}

The grounded theory derived from the research is presented in Table 1. From Table 1, it can be deduced that senior managers employed by the chaebol embrace continual communication from the stance that "learning" is important but needs to be placed in a certain framework in order that account can be taken of the "Situational condition(s)" confronting the organization and in addition, give rise to a solution, which is termed "The means". The emphasis is for the organization to improve its capability through staff sharing information, developing knowledge and utilizing skills. Potentially, this has political implications and senior managers need to understand how they are going to deploy the "Tools" to achieve the objectives set by satisfying two different audiences (the state and the organization's customers).

It is clear that staff are expected to share information, however, it has to be remembered that there is risk associated with this. Managers need, therefore, to be aware of the level of 'trust' that exists as building 'trust' based relationships takes time. One way in which Korean companies nurture trust based relationships is by recruiting via tried and tested means (Gong-che and Yon-go). As well as the ability of an individual being deemed important, so too are 'family-ties', which relate to networking and 'face' of the family. This 
is because the family's reputation in the community carries weight and an individual's loyalty to the organization is paramount.

\section{INSERT TABLE 1 HERE}

With reference to a "High level of customer service" outlined in Figure 1, Respondent one provided some useful insights:

"....customers are viewed very broadly by the company's staff and if the senior product manager comes to me in the marketing department he is my customer. I will give him every assistance that I can ..... retailers and distributors in the area are also costumers and require different information than the end user/customer..... we do have a high level of awareness of the requirements and information needed. The MD reads all the letters of complaint that are addressed to him, and he sees all of the replies.... If we felt something is causing a customer problems, then we will act very quickly and speak to our colleagues immediately."

The process of continual communication involves connecting to various but relevant channels and people and is the main component of the interactional strategies. The "Corollary" can be placed in the context of improving the organization's capabilities through information sharing in order to produce products that meet customer expectations and involves knowledge and skill development. Evidence for this comes from a senior manager known as Respondent two, who stated: 
“... as we do share more and communicate with them, you can make better decisions because you can make the decisions based on more information."

It can be noted that the "Tools" (cultural influence and relationship management) are associated with the way in which information is disseminated and the impact it has on how the organization's marketing strategy is shaped and how a learning plan is incorporated, and manifests in how the company deploys its corporate strategy and enhances its brand name. For example, another senior manager, Respondent three stated:

“Compliance with regulation is important but there are better avenues [people] to get feedback from such as the local standards trading office ... and if they have a problem they can come to me or us to resolve the customer's problem ... product improvement .. to get feedback on whether or not we have any product issues on a particular product through customer feedback ..... not only through a formal way...".

Respondent three continued:

"our aim is to promote ourselves to the trade first, .... we are going to promote ourselves to the consumer...make sure the trader is comfortable with us ... and what we stand for then move to the consumer and do exactly the same thing... Make them more aware, ... high quality products if you want the best product ... giving good value for money". 
It can be argued that cultural influence (Tools) deployed in the chaebol is a stimulus and encourages individual members of staff to set high goal(s) of achievement that are consistent with the organization's goals and result in individual members of staff interacting with other members of staff through group work. "Corollary" can be viewed as a facilitator as it provides guidance vis-à-vis staff learning activities and performance measures, and it encourages fore-sight. This outcome is supported by the work of Lee and Trim (2013) who explain how a collectivist culture underpins the marketing strategy process. For example, in order to motivate staff to share information, staff need to be aware of the importance associated with meeting local regulations and ensuring that customers are comfortable with the company's way of doing business/its image. This means that a formal and structured reporting system needs to be in place.

Through the process of "Organizational learning" as depicted in Figure 1, open communication and information sharing will improve customer service continually. Evidence of this comes from Respondent three who commented:

"We talk to them, everyone, ... our director with end users or in my case a lot of time with our competitors,.... go to industry meetings.... friends who work for other companies .... and say, we are looking for your products $\mathrm{X}$ and $\mathrm{Y}$.... that is how we get feedback.... if they [customers] are not happy with our delivery, ... they were quick to tell us, ..., because they have a choice of where they can buy from,... if we know what the problem is, then we are in a position to act on it and we can take steps to fix it."

Another senior manager, Respondent two, added: 
“... I think, if you have a common culture with your partners, you can say that you can communicate with them very well. This means that they know each other's changes, so they can respond to the changes accordingly and quickly."

This outcome supports the work of Harvey and Denton (1999), Schepers, Falk, de Ruyter, de Jong and Hammerschmidt (2012) and Lukas, Whitwell, and Heide (2013). It can be observed from the quotations that there are two issues. First, how to relate quality and price in order to provide a better service to customers. This is done by delivering an acceptable product (level of technology) at an appropriate price. Second, the attitude of staff towards sharing relevant/necessary information and the type of interaction involved. As regards the interaction of staff, it can be understood that "culture" encourages staff to engage in 'open communication' that is directly focused on 'problem-solving' and individuals taking responsibility for certain actions. The process of maintaining trust based relationships is reinforced by the fact that an individual safeguards their own "face". An open communication style also enables staff in other functions/units/partner organizations to be involved in solving customer related problems and helps them to devise initiatives to improve products/services on an ongoing basis.

In order to maintain and increase the organization's reputation, capability and reliability, staff are committed to the concept of 'continual improvement'. This resonates at the subconscious level and facilitates open communication that results in the evaluation of the firm's product/service. The management procedures in place ensure that other functions/units/partner organizations do the same. To understand how people from a collectivist culture such as Korea undertake evaluations and maintain/save 'face', it is necessary to place the concept within a social status context. Kim and Nam (1998, p.529) 
suggest that Asian managers think in terms of "source, motive, goal, processes, and consequences". The concept of face is rooted in Confucian thought and is typical of a collectivist culture, and can be better appreciated by studying the vertical and horizontal relationships among groups of people. Face requires that people control their emotions and their attitudes, and maintain harmony with colleagues and customers. This can also be translated into respecting customers and has implications regarding forming and maintaining long-term relationships. Essentially, the key point is whether somebody "fits-in" as opposed to "stands-out" within a group (Brown \& Levinson, 1987). Hence managers employed by a cheabol are able to take a balanced view of what the customer needs and thus avoid what is known as overshooting (Lukas, Whitewell \& Heide, 2013). For example, Respondent three intimated:

"I think, we are very confident with the level of our staff, staff working with customer information.... if you offer an overall service ... it is important to think in terms of maximising profit, so it is important to get the best possible price and have as few problems afterwards as possible".

It is interesting to note that when one relates the attributes of "continual communication" (Corollary) with "cultural influence and relationship management" (Tools), social interaction plays an important role and allows an organization to produce a marketing strategy that results in the company being different from its competitors.

It has often been observed that Korean staff are hard working and committed to the organization (Ungson, Steers \& Park, 1997; Lee, 1998-1999); and this can be interpreted as Korean people being highly elitist and pragmatic, yet being socialized into the organization's fabric (Steers, Shin \& Ungson, 1989; Kim \& Nam, 1998). Socialization has a two fold 
purpose: first, it is to make an individual aware of the views of their peers and also their line (senior) manager(s). 'Losing face' (either one's own or the group's) may have unforeseen consequences. The 'sense of losing face' does not simply relate to maintaining the equilibrium associated with group harmony, but needs to be placed in a reciprocal, relational context (Ho, 1976; Kim \& Nam, 1998). Second, it is to ensure that Korean people try to find their place in a social hierarchy by fostering harmonious and interdependent relationships with their group members. Acceptance is based on specific subject knowledge and diplomatic/management skill that is viewed as important as it allows an individual to progress through the organization's hierarchy.

As regards "Group behaviour" as depicted in Figure 1, in relation to marketing strategy, Respondent two stated:

\begin{abstract}
"Each department/group(s) is empowered to pass on knowledge relating to value creation and this means that the middle management group share their viewpoint/cultural value system with their junior management group".
\end{abstract}

This is evidence that it is the middle managers who determine the level of autonomy and create and develop an appropriate learning environment in which junior staff relate to the values of the organization and become immersed in the organizational value system (O’Leary, Mortensen \& Woolley, 2011). By middle managers adopting a flexible approach, staff are stimulated to develop original ideas/views that are aimed at solving complex problems of a multi-faceted nature (Goffin \& Koners, 2011; Sivasubramaniam, Liebowitz \& Lackman 2012). In the case of the company that participated in the research outlined in this paper, middle managers interpret, direct and explain what government is attempting to achieve and how this will benefit the company and its employees. Through the process of 
fostering close interaction among staff, people will be motivated and will want to be associated with the main or ingroup. Being a member of the ingroup has psychological value and will incentivize people and encourage them to share information in order to achieve better performance. For example, Respondent three was firm in their view about the process of fostering interaction:

“...to generate enthusiasm among staff requires making them feel more an integral part of the company, because there are big competitors out there and getting them [staff] involved in the business process means people will look at other people in the company and will look at me, and look at the other marketing people and will see that their perception of what I do is important..".

Also, another senior manager, Respondent two, reiterated this view by stating: "If we do not work together, it is difficult to lead this organization”. We can deduce that middle managers need to play a proactive role vis-à-vis solving complex marketing problems because of the level of complexity and uncertainty that exists. Within the context of improving performance, the work-group assumes the role of the performance evaluator (social legitimacy) and if an individual does not or cannot meet the expectations of the group, then the individual/group may lose face (Ouchi, 1980). This suggests that 'face' has two facets: first, it is associated with sharing collected information; and second, the process of acquiring skills is viewed as building organizational capability. Please note in Figure 1, the role of the group is influential with regards to marketing strategy implementation, which results in a high level of customer service.

By an individual strengthening their capability (skill base), they are perceived as being flexible and trustworthy. For example, Respondent two stated: "When a person 
needs a specific type of training then the person and his/her senior manager discuss the issue and decide what is appropriate." The same manager also stipulated: "Where necessary, we also link with local universities for special needs, and that means specific training". This is viewed positively because specific training is to support and build an individual's skill level and capability. This commitment to staff development is essential with respect to reinforcing the fact that the organization is customer focused. Interaction among and between staff members is encouraged so that information sharing occurs and the group is able to achieve the targets set (Janelli, 1993). On reflection, it can be argued that 'group belongingness' is associated with increasing 'face' within a group, and results in creating 'opportunities' to enhance an individual's skill and knowledge base.

With regards to the "Organizational value system" as depicted in Figure 1, it can be suggested this is viewed in relation to enhancing customer service through trustworthy behaviour. For example, Respondent two stated:

"Staff have the manual from HQ relating to marketing, even the logo is defined, what is the logo's meaning results in a consistent approach because there is a need to be consistent on a global basis. How to implement marketing strategy ... each managing director .. can apply their own creativity and have their own action plan based on their own idea, ... but basically the company has only one strategy."

Furthermore, Respondent two added:

“.. our agencies, although our marketing managers and staff do control the various agencies, produce feedback to satisfy our demands and/or requirements ... the agencies and their professionals, help us to define the quality". 
By allowing senior managers to have flexibility and draw up their own action plans, staff feel that their work is valued and therefore develop an emotional commitment to the organization. This means that when staff engage with external organizations - which form an integral part of the operational element of the organization - they identify, more consciously, with individuals they consider to be reliable and who have appropriate skills and knowledge. The key being to build relationships with individuals that are prepared to share information that results in mutual benefit. For example, data and information is generated through various organizations (e.g., consumer associations, specialist industry consultants, and market research companies) and is made available to staff in partner organizations in order that the marketing strategy and overall reputation of the organization are enhanced.

It appears that managers reflect on the benefit of 'learning' from different types of information source and this encourages individual staff to collaborate and be part of a crossfunctional team and contribute to the development of the organization's memory. In the case of relationship building with overseas organizations, it is likely that a formal contract is entered into in order to prevent individualistic or opportunistic behaviour. Respondent two provided some useful insights into this:

\footnotetext{
"Formal contracts are necessary if the implementation of market-oriented concept known as reducing opportunistic behaviour and sharing information for the benefit of the group/company are to dominate and be seen as relevant ....the sharing of information is a key issue. As regards communication, as I have always stressed, two things in business are most important, one is communication and the other is trust about the service which the organization provides .... so sharing information about the market and the concept of customer orientation is very important....customer satisfaction and cost 
effectiveness need to be interpreted from the range of products and it is unavoidable to link customer satisfaction to the company's budget/cost.... you have to have trustworthy relationships, so then you can build loyalty".

It is through the process of developing trustworthy behaviour that a pro-active approach materializes and results in new product development being placed within a holistic programme of managing change (Salomo, Kleinschmidt \& de Brentani, 2010). In the case of the company that participated in the research, it is evident that the organizational cultural value system gave rise to a distinct marketing strategy that is underpinned by managers being committed to sharing knowledge, experience and wisdom with staff lower down the organizational hierarchy. The strategic marketing approach was adopted and placed much emphasis on staff collecting market intelligence and identifying company-product-market fit requirements. The distinct marketing strategy developed is reinforced by the organization's dominant logic as business relationships are internally and externally orchestrated (Yamin \& Andersson, 2011, pp.152-154). Communication is, therefore, to be viewed from the perspective of skill set enhancement, the objective of which is to enable employees to ask the right questions and find unique solutions to solving problems relating to operational issues. In precise terms, by encouraging information sharing it is possible to improve social integration within and between organizations and ultimately, improve organizational performance and competitive standing within the industry. It is useful to remember that knowledge sharing, training and development, and learning from experience (Friesl, 2012, p.334) are all associated with internal learning, however, in order to fully understand what learning involves, it is necessary to take into account collaborative learning and market-based learning as well (Friesl, 2012, p.339). Bearing in mind the above, Figure 1 has been extended and modified. Please consult Figure 2. 


\section{Environmental characteristics, attributes of Korean companies, and propositions development}

There is a developing literature relating to how Korean companies are managed, and a summary of relevant environmental characteristics and company attributes appear in Table 2 . As can be noted from Table 2, marketing managers in Korean companies are focused on the operating environment and this requires that they identify what data and information is needed in order to enhance the marketing strategy formulation process within the organization. It can also be noted that managers in Korean companies are aware of the interplay between the marketing dimension (please see the "External environment" in Table 2 and "Marketing strategy" and "High level of customer service" in Figure 2) and the human factor dimension (capability of the employee(s) as determined by their behaviour) (please see the "Internal environment" in Table 2 and "Group behaviour" in Figure 2), and this has been taken into account when creating the profile outlined in Table 2.

INSERT TABLE 2 HERE

Reflecting on the above, Table 1 indicates how marketing managers in the Korean electronics company under investigation develop marketing strategies that are culturally bound and which are underpinned by the organizational learning concept. The chaebol's organizational learning model is made explicit and allows us to identify how the "Tools" 
(defined as cultural influence and relationship management) form the intervening conditions; and how the "Corollary" (defined as continual communication) form the action/interactional strategies.

From the analysis and interpretation, it can be deduced that managers employed by the Korean chaebol that participated in the study embrace the concept of organizational learning and they adjust and apply it in order to ensure that harmony exists. Traditional Korean cultural values evident in society, permeated the organization's value system. Bearing this in mind, the research outcome visualises how managers in chaebols adapt and guide the process of organizational learning in a culturally and environmentally specific context. The attributes identified in Table 1 are derived from the analysis and interpretation of the primary data. When we analysed the data we also reflected on the material from the literature review outlined in Table 2. This allowed us to identify and define the categories and variables. By applying the "paradigm model" that we did, we established a pattern of how senior marketing managers in the Korean company devised a marketing strategy. Table 1 outlines clearly what is meant by the term "organizational learning" and how the concept was deployed by staff in the company (please consult the column denoted Chaebol's organizational learning model), which can be considered multi-layered and hierarchical but tightly inter-connected and executed distinctively (as is evidenced by the column entitled: “Attributes relating to strategy deployment").

With respect to causal conditions in Table 1, we refer to a target of economic growth specified in a certain time period, set out by the state and underpinned by industry specific policies. We referred to this as the 'situational condition'. This can be deemed valid as managers based in South Korea relate the objectives of the company to those of the government (see Table 2)(Song, 1992; Ungson, Steers \& Park, 1997; Jeong, 1999; Kim \& Yi, 1998-1999; Shin, 19981999; Lee \& Trim, 2012). 
As regards the phenomenon, in Table 1, we refer to the 'ethos of the firm' as managers increase the reputation of the company through achieving targeted growth in line with government objectives, and it is evident that customer service is pivotal as regards ensuring that the needs of customers are met. Hence, managers are required to identify skilled and knowledgeable staff, and identify with government economic growth targets. This has serious implications for companies in South Korea as the government controls bank accounts as well as special schemes for specifically defined industry and company performance (please see the "Leadership" domain in Table 2) (Chen, 1995; Ungson, Steers \& Park, 1997; Kim \& Yi, 19981999).

The context, is referred to as "The means" in Table 1 as it relates to how an organization achieves its ethos, which is based on monitoring activities to improve organizational capability through sharing information and enhancing the level of knowledge and skills through recruitment activities. Managers in Korean companies are aware that they need to identify key government representative(s) and to link the company's strategic focus with industry policy, and remain flexible in order to build organizational capability (please see "Role of manager"; "Control"; "Influence of the national cultural value system on the orgnaization's value system" in Table 2)(Kim \& Yi, 1998-1999; Lee, 1998-1999; Shin, 1998-1999; Jeong, 1999; Lee \& Trim, 2013).

Turning next to intervening conditions in Table 1, we relate this aspect to cultural influence (Confucian thought), and how managers in a chaebol establish their organization's ethos and devise and implement management practices. Therefore, we regard culture as a 'Tool' for the process of recruiting new members of staff (via Yon-go and Gong-che). This approach to recruitment promotes a sense of "family" culture within the company. One of the key characteristics of chaebols is that they are controlled by family ties and this has implications with respect to managing day-to-day operations. In order to achieve the strategic objectives, 
individual members of staff need to be viewed as trustworthy and flexible (Lee, 1998-1999; Whang, 1998-1999; Jeong, 1999; Lee, 2010). This translates into an employee being capable of completing a task(s) within a specific time frame and at the required/anticipated quality. This has implications as regards how the process of learning is managed within the organization as it places individual learning within an institutional context.

The action/interactional strategies in Table 1 are interpreted in the context of 'Corollary' as it relates directly to managing the process of improving the organization's capability to achieve the ethos of the firm. This is so that it meets the objectives set and the country achieves the growth target(s) set by the state. In the process, customer needs are met and a balance is achieved between price and quality (eg., the level of technology embedded in the product offering for example).

During the management process, it is interesting to note how "continual communication" manifests. In order that communication is continual, and is viewed as productive within a chaebol, it is necessary for two conditions to be satisfied: one relates to the place where the individual concerned studied (e.g. university), and which is highly influential with respect to shaping perceptions regarding an individual's skill base and knowledge; and another aspect is whether the individual has the right political connection(s) within the chaebol as well as the state (Lee, 2010) to be able to network effectively.

Because marketers need to align customer focus with customer satisfaction (Harvey \& Denton, 1999), marketing managers need to understand how the company rewards individual and team performance (Faure, 2009). This is due to the fact that both the staff behaviour dimension (human factor) and the marketing dimension are linked. By encouraging employees to use their discretion and take the initiative when interacting with customers, customer stewardship control will result that goes beyond the traditional customer orientation approach (Schepers, Falk, de Ruyter, de Jong \& Hammerschmidt, 2012). The main benefit of the 
customer stewardship control approach is that it highlights how marketers, as decision makers and/or facilitators, motivate staff to share information among their colleagues in order to maintain the organization's reputation (Lee and Trim, 2013). From the above, it is evident that senior managers in the Korean chaebol identify individuals both internal to the organization and external to the organization that they have trust in to build long-term working relationships with. From the research undertaken, we argue that the 'Tools' can be utilized to improve an organization's capability and increase opportunities associated with information sharing, and knowledge and skill development. For instance, in order that staff deliver what is required of them, they need to be proactive when searching for information to resolve identified problems. Trustworthiness and loyalty (shin) are important cultural characteristics. An additional point that needs attention is the relationship between the 'Tools' and 'Corollary' as the nature of interactions among staff, and staff and managers can be viewed from the perspective of sub-group interaction, which is formal and informal.

Employers have an expectation of what an individual will bring with them in terms of the right/desired knowledge, skills and network, collectively known as 'Migratory Knowledge,' or will contribute in the way of shaping and implementing different types of marketing strategy. This ultimately results in several possible 'Outputs' as is evidenced in Table 1. New members of staff are recruited and immersed in the organization's cultural value system, Shin (trust, loyal) and Suh (order), and because of this the culturally embedded group norms directly influence how the team achieves the group targets set. By achieving the targets set, the individual team members are viewed as being loyal to their manager(s) (Ungson, Steers \& Park, 1997; Lee, 1998-1999). Loyalty in terms of group and sub-group association, is measured from the stance of quality of interaction and staff are rewarded through career progression. 
By reflecting on these points, it is possible to revisit the work of De Brentani and Kleinschmidt (2004) regarding how marketing managers establish an appropriate organizational cultural value system and how they foster innovativeness (Yoo \& Frankwick, 2012) and thus identify ways in which to improve upon the level of customer service provided. Bearing these points in mind, we cite two propositions.

Proposition 1:If senior management provide guidance as to how data and information is collected from the external environment and how the findings are used in the marketing strategy process, the interaction of in-house company personnel will be improved and this will enhance the marketing decision-making process.

Proposition 2: If marketing managers engage in open communication in order to motivate staff and share information with managers in other business units, then customer service will be continually improved.

Regarding group and intergroup relations, minority positions and dominant positions, and information processing, it is necessary to think in terms of power, and assertive and defensive group behaviour, if that is group dynamics are to be understood (Simon, Aufderheide \& Kampmeier, 2004). The role of power is, we feel, important because it provides insights into how multiple team membership influences individual learning, team learning, and ultimately productivity (O’Leary, Mortensen \& Woolley, 2011). Goffin and Koners (2011) indicate that learning occurs at various levels such as the individual level, the project team level and the project-to-project level, and a combination of all these levels. This links directly with how knowledge is developed within an extended organizational context; and how learning activities are used to assist the process of information sharing. Group performance needs to take into 
account how leadership of a team is measured against team tenure and functional diversity (Sivasubramaniam, Liebowitz \& Lackman, 2012). In addition, it is relevant, we feel, to reflect on such issues as an individual's inclusion into a group and also a team's identity (Ellemers, Sleebos, Stam \& de Gilder, 2013). Loyalty is perceived as an important quality in Korean society and it relates to the trustworthiness of an individual (Song, 1992; Lee, 1998-1999). In return for being loyal, a member of staff expects their manager(s) to protect/support them and this is related to well being and is grounded in the concept of 'mutuality'. However, one interesting point to note is that according to Tu Wei-ming (cited in Ungson, Steers and Park, 1997), Confucianism not only emphasises 'obedience' to government, but can be more widely interpreted as 'accountability' of government. Therefore, the concept of 'mutuality' encompasses relationship building with an emphasis on 'faithfulness', 'loyalty'; and the role that a subordinate plays. Therefore managers need to be seen as fair, adaptable to a situation and able to manage capable staff (Outputs 2 and 3 in Table 1). The concept of mutuality stems from Confucian thought and is known to contribute to the emergence of new South Korean business models, which embrace diversity in order to acquire the necessary skills to be flexible and adaptable (Lee, 2010).

When a collectivist identity is evident, individuals may both support and represent this identity (Worchel \& Coutant, 2004), however, creative tension will arise from time to time, and managers need to exercise perseverance and patience (Senge, 1999). Because marketers work with multiple teams on complex products/problems they will need to take note of how group identity and interdependency shape a team's development (Glynn, Kazanjian \& Drazin, 2010). In terms of managing tension and performance, it should be noted that an individual's performance may in some way be related to their risk perception (McNally, Durmusoglu \& Calantone, 2013); and also, be linked with the amount of autonomy a team/function has. 
It is useful to note the contribution to the body of knowledge made by Ellemers, Sleebos, Stam and de Gilder (2013), and to make reference to Edmondson and Nembhard (2009, pp.125-126) who claim that struggling with challenges such as cross-functionality and conflict, enables team members to build capabilities for learning which facilitates collaboration, as crossfunctional teams are viewed as providing "greater access to more and different types of information".

In a collectivist culture, team cohesiveness and team building, and maintaining trustworthy relationships, are the concerns of senior management. Lee (2004) suggests that trust is influential vis-à-vis facilitating the relationship building process and developing boundaryspanning skills. Members of a group identify appropriate individuals outside of their team who can provide information that can be acted upon to help the group. This we would argue is a natural process in a collectivist culture, where each group is perceived as being an integral part of a larger group. It is possible to suggest that the collectivist approach to learning has given rise to what is generally known as organizational memory, which is: "all the knowledge that a firm gathers. This knowledge requires proper storage and availability to all the individuals to facilitate its retrieval as necessary" (Santos-Vijande, Lopez-Sanchez \& Trespalacios, 2012, p.1081). This is a critical aspect to an organization that is intent on developing a new product as the organization's collective knowledge will facilitate the process of defining and redefining a product's target market (Salomo, Kleinschmidt \& de Brentani, 2010). We propose two additional propositions.

Proposition 3: The tendency and degree of information sharing among marketing staff will be influenced by the sense of belongingness an individual has to a team/group. 
Proposition 4: By developing emotional commitment, trustworthy behaviour will result that enhances the organization's reputation.

\section{Conclusion}

Reflecting on the first question posed in this exploratory study, it can be deduced that marketing staff in the chaebol are engaged in a continuous process of acquiring and utilizing knowledge through their various relationships (e.g. with other staff and customers) and demonstrate their loyalty and commitment to the group/organization. In return, they are accepted by their peers and the organization. The relevant work experience gained by staff is deemed of value to the company as it facilitates the process of organizational learning. As regards the second research question, it can be argued that the marketing decision-making process itself is flexible and multi-layered, and needs to be viewed as pragmatic as the customer service policy is placed within a situational context. Hence marketing staff need to be open to a range of inputs (and influences) from different sources (internal and external to the organization).

We believe that the research outlined in this paper has provided useful insights into how information sharing can contribute to knowledge creation in an organization with a collectivist culture. Knowledge creation does, we feel, increase an organization's commitment to developing an innovative organizational culture that facilitates experimentation, which results in new alternative strategies being put forward (Wei, O’Neill, Lee \& Zhou, 2012). We consider there is value in what Okhuysen and Bonardi (2011, p.7) claim, namely that "Areas of new relevance in management can also benefit from explanations that combine theoretical lenses". This links clearly with the line of argument purporting that more needs to be done in the area of interpreting the practical and operational issues associated with international research findings (Sinkovics \& Penz, 2011, p.706). 
Furthermore, we adhere quite firmly to the belief that producing a "unifying theory" (Crossan, Maurer \& White, 2011) or working towards such an objective, is worthwhile and requires that researchers rise to the intellectual challenge and ensure that research findings permeate into the learning/teaching environment. By doing this, we will help to develop knowledge in the way outlined by Yadav (2010) and this should foster additional collaboration among academics of an interdisciplinary and multi-disciplinary nature.

\section{Limitations and Research Implications}

The authors recognize that by analzying and interpreting data from three in-depth, personal interviews with senior marketing managers employed by one chaebol only the research findings can be considered limited. It can also be suggested that the grounded theory approach has its critics and is known to have a number of limitations (Suddaby, 2006; Urquhart, Lehmann \& Myers, 2010), however, the grounded theory approach is recognized as an interpretive process, contributes to the development of theory (Urquhart, Lehmann \& Myers, 2010), and allows the researcher a certain degree of flexibility (O'Brien \& Linehan, 2014). What is encouraging is that several areas for further research emerged from the study and we suggest that work in the area of reducing cultural distance can be undertaken in order to explain how specific aspects of marketing can be improved through information sharing involving in-house groups (interpreted as intra-group activity) and partnership arrangements (interpreted as inter-group activity). Should this be the case, the work undertaken by Wei, O'Neill, Lee and Zhou (2012), can be taken a stage further and additional knowledge generated into how the information-sharing process is reinforced by cultural value systems and how marketing staff and human resource management specialists can work together in order to create organizational uniqueness. This would reinforce the work already undertaken by Drechsler, Natter and Leeflang (2013). It would also add to the knowledge already 
produced by Salomo, Kleinschmidt and De Brentani (2010) and take forward the insights provided by Henard and McFadyen (2005) into how a company can exploit knowledge and how appropriate research initiatives can be linked with a persistent investment strategy so that limited resources are optimized.

A comparative longitudinal study involving staff from a different cultural setting should be undertaken in order to establish how staff engage with multiple teams and set tasks, how they are assigned roles and how individual team members identify with other organizational teams members (Glynn, Kazanjian \& Drazin, 2010). By undertaking additional research such as this, it will be possible to produce new insights into social identity theory (Ellemers, Sleebos, Stam \& de Gilder, 2013, p.22). As a result, researchers will have a more in-depth appreciation of corporate management learning (Easterby-Smith \& Thorpe, 1997) and it should provide evidence as to how team members within organizations are rewarded (Faure, 2009). This would be beneficial as it would allow a more in-depth appreciation to be made of how individuals move from an in-group to an out-group and vice versa.

\section{References}

Aaker, D. A. (1992). Strategic marketing management. Chichester: John Wiley and Sons Inc.

Anh, P.T.T.C., Baughn, N.T.M.H., \& Neupert, K.E. (2006). Knowledge acquisition from foreign parents in international joint ventures: An empirical study in Vietnam. International Business Review, 15, 463-487.

Baker, M. (1996). Marketing strategy. In M. Warner (Ed.), International encyclopaedia of business and management (pp.3.333-3,347). London and New York: Routledge.

Brown, P., \& Levinson, S. (1987). Politeness: Some universals in language use. Cambridge, UK: Cambridge University Press.

Chen, M. (1995). Asian management systems: Chinese, Japanese and Korean styles of business. London and New York: Routledge.

Crossan, M. M., Maurer, C.C., \& White, R.E. (2011). Reflections on the 2009 AMR decade award: Do we have a theory of organizational learning? Academic Management Review, 36, 446-460. 
De Brentani, U., \& Kleinschmidt, E.J. (2004). Corporate culture and commitment: impact on performance of international new product development programs. Journal of Product Innovation Management, 21, 309-333.

Deshpande, R., Farley, J.U., \& Webster, F.E. (1993). Corporate culture, customer orinentation, and innovativeness in Japanese firms: A quadrad analysis. Journal of Marketing, 57, 23-37.

Drechsler, W., Natter, M., \& Leeflang, P.S.H. (2013). Improving marketing's contribution to new product development'. Journal of Product Innovation Management, 30, 298-315.

Easterby-Smith, M., \& Thorpe, R. (1997). Research traditions in management learning. In J. Burgoyne, J., \& M. Reynolds (Eds.), Management learning: Integrating perspective in theory and practice (pp.38-53). London: Sage Publications.

Edmondson, A.C., \& Nembhard, I.M. (2009). Product development and learning in project teams: The challenges are the benefits. Journal of Product Innovation Management, 26, pp.123138.

Ellemers, N., Sleebos, E., Stam, D., \& de Gilder, D. (2013). Feeling included and valued: How perceived respect affects positive team identity and willingness to invest in the team. British Journal of Management, 24, 21-37.

Faure, C. (2009). Attribution biases in the evaluation of new product development team members. Journal of Product Innovation Management, 26, 407-423.

Ferlie, E., \& McNulty, T. (1997). "Going to market": Changing patterns in the organization and character of process research. Scandinavian Journal of Management, 13, 367-387.

Friesl, M. (2012). Knowledge acquisition strategies and company performance in young high technology companies. British Journal of Management, 23, 325-343.

Glynn, M.A., Kazanjian, R., \& Drazin, R. (2010). Fostering innovation in complex product development settings: The role of team member identity and interteam interdependence. Journal of Product Innovation Management, 27, 1,082-1,095.

Goffin, K., \& Koners, U. (2011). Tacit knowledge, lessons learnt, and new product development. Journal of Product Innovation Management, 28, 300-318.

Gonzalez-Padron, T.L., Chabowski, B.R., Hult, G.T.M., \& Ketchen, D.J. (2010). Knowledge management and balanced scorecard outcomes: Exploring the importance of interpretation, learning and internationality. British Journal of Management, 21, 967-982.

Harvey, C., \& Denton, J. (1999). To come of age the antecedents of organizational learning. Journal of Management Studies, 36, 897-918.

Henard, D.H., \& McFadyen, M.A. (2005). The complementary roles of applied and basic research: A knowledge-based perspective. Journal of Product Innovation Management, 22, 503-514. 
Ho, D.Y.F. (1976). On the concept of face. American Journal of Sociology, 81, 867-884.

Janelli, R. L. (1993). Making capitalism. Stanford, CA: Stanford University Press.

Jarratt, D., \& Stiles, D. (2010). How are methodologies and tools framing managers' strategizing practice in competitive strategy development? British Journal of Management, $21,28-43$.

Jeong, J. (1999). Personnel management policies for workplace restructuring and their implications for industrial relations: A case in Korea from a comparative perspective. The International Journal of Human Resource Management, 10, 89-107.

Kim, L. (1997). The dynamics of Samsung's technological learning in semiconductors. California Management Review, 39, 86-100.

Kim, J.Y., \& Nam, S.H. (1998). The concept and dynamics of face: Implications for organizational behaviour in Asia. Organization Science, 9, 522-534.

Kim, L. \& Yi, G. (1998-1999). Reinventing Korea's national management system. International Studies of Management and Organization, 28, 73-83.

Lee, H-C. (1998-1999). Transformation of employment practices in Korean businesses. International Studies of Management and Organization, 28, 26-39.

Lee, Y-I. (2004). Customer service and organizational learning in the context of strategic marketing. Marketing Intelligence \& Planning, 22, 652-662.

Lee, Y-I. (2010). A comparison of the Japanese and South Korean mindset: Similar but different management. In J., Syed, \& M. Ozbilgin (Eds.). Diversity management in asia (pp.248-277). Cheltenham: Edward Elgar.

Lee, Y-I., \& Trim, P.R.J. (2012). How mutuality reinforces partnership development: Japanese and Korean marketing perspectives. Industrial Marketing Management, 40, 770779 .

Lee, Y-I., \& Trim, P.R.J. (2013). An explanation of how a collectivist culture underpins the marketing strategy process in Japanese and South Korean electronics companies. Journal of Global Scholars of Marketing Science: Bridging Asia and the World, 23, 314-337.

Lee, Y-I., \& Trim, P.R.J. (2014). How the organizational learning concept is utilized to produce a high level of customer service: A Korean perspective. 2014 Global Marketing Conference $\left(15^{\text {th }}\right.$ to $18^{\text {th }}$ July). Singapore: Sands Expo and Convention Centre, Marina Bay Sands.

Lukas, B. A., Whitwell, G.J., \& Heide, J.B. (2013). Why do customers get more than they need? How organizational culture shapes product capabilities decisions. Journal of Marketing, 77, 1-12. 
McNally, R.C., Durmusoglu, S.S., \& Calantone, R.J. (2013). New product portfolio management decisions: Antecedents and consequences. Journal of Product Innovation Management, 30, 245-261.

Moon, H., Miller, D.R., \& Kim, S.H. (2013). Product design innovation and customer value: Cross-cultural research in the United States and Korea. Journal of Product Innovation Management, 30, 31-43.

O'Brien, E., \& Linehan, C. (2014). A balancing act: Emotional challenges in the HR role. Journal of Management Studies, 51, 1,257-1,285.

Okhuysen, G., \& Bonardi., J-P. (2011). Editors' comments: The challenges of building theory by combining lenses. Academy of Management Review, 36, 6-11.

O’Leary, M.B., Mortensen, M., \& Woolley, A.W. (2011). Multiple team membership: A theoretical model of its effects on productivity and learning for individuals and teams. Academy of Management Review, 36, 461-478.

Orton, J.D. (1997). From inductive to iterative grounded theory: Zipping the gap between process theory and process data. Scandinavian Journal of Management, 13, 419-438.

Ouchi, W. G. (1980). Market, bureaucracies and clans. Administrative Science Quarterly, $25,129-141$.

Parasuraman, A., Zeithaml, V.A., \& Berry, L.L. (1985). A conceptual model of service quality and its implications for future research. Journal of Marketing, 49, 41-50.

Park, B.I. (2011). Knowledge transfer capacity of multinational enterprises and technology acquisition in international joint ventures. International Business Review, 20, 75-87.

Patton, M.Q. (1990). Qualitative evaluation and research methods. Newbury Park, CL: Sage Publications.

Rust, R.T., Thompson, D.V., \& Hamilton, R.W. (2006). Defeating feature fatigue. Harvard Business Review, 84, 98-107.

Salomo, S., Keinschmidt, E.J., \& de Brentani., U. (2010). Managing new product development teams in a globally dispersed NPD program. Journal of Product Innovation Management, 27, 955-971.

Santos-Vijande, M.L., Lopez-Sanchez, J.A., \& Trespalacios, J.A. (2012). How organizational learning affects a firm's flexibility, competitive strategy, and performance. Journal of Business Research, 65, 1,079-1,089.

Schepers, J., Falk, T., de Ruyter, K., de Jong, A., \& Hammerschmidt, M. (2012). Principles and principals: Do customers stewardship and agency control compete or complement when shaping front line employee behaviour? Journal of Marketing, 76, 1-20.

Seidman, I. E. (1991). Interviewing as qualitative research: A guide for researchers in education and the social sciences, New York: Teachers College, Columbia University. 
Senge, P.M. (1999). The fifth discipline: The art \& practice of the learning organization. London: Random House.

Shin, Y.K. (1998-1999). The traits and leadership styles of CEOs in Korean companies. International Studies of Management and Organization, 28, 40-48.

Simon, B., Aufderheide, B., \& Kampmeier, C. (2004). The social psychology of minoritymajority relations. In M. B. Brewer \& M. Hewstone, (Eds.), Self and social identity (pp.278297). Oxford: Blackwell Publishing.

Sinkovics, R.R., \& Penz, E. (2011). Multilingual elite-interviews and software-based analysis: Problems and solutions based on CAQDAS. International Journal of Marketing Research, 53, 705-724.

Sivasubramaniam, N., Liebowitz, S.J., \& Lackman, C.L. (2012). Determinants of new product development team performance: A meta-analytical review. Journal of Product Innovation Management, 29, 803-820.

Song, B-N. (1992). The rise of the Korean economy. Hong Kong: Oxford University Press.

Steers, R., Shin, Y., \& Ungson, G. (1989). Chaebol: Korea's new industrial might. New York: Harper Row.

Strauss, A., \& Corbin, J. (1990). Basics of qualitative research. Newbury Park, CL: Sage Publications.

Strauss, A., \& Corbin, J. (1998). Basics of qualitative research: Techniques and procedures for developing grounded theory. London: Sage Publications.

Suddaby, R. (2006). From the editors: What grounded theory is not. Academy of Management Journal, 49, 633-642.

Tuominen, M., Rajala, A., \& Moller, K. (2004). How does adaptability drive firm innovativeness? Journal of Business Research, 57, 495-506.

Ungson, G.R., Steers, R.M., \& Park, S-H. (1997). Korean enterprise: The quest for globalization. Boston, Massachusetts: Harvard Business School Press.

Urquhart, C., Lehmannand, H., \& Myers, M.D. (2010). Putting the 'theory' back into grounded theory: Guidelines for grounded theory studies in information systems. Information Systems Journal, 20, 357-381.

Wei, Y., O’Neill, H., Lee, R.P., \& Zhou, N. (2012). The impact of innovative culture on individual employees: The moderating role of market information sharing. Journal of Product Innovation Management, 1-15, doi: 10.1111/j.1540-5885.2012.01000.x.

Whang, I-C. (1998-1999). Awareness of social responsibility by Korean managers in marketing practices. International Studies of Management and Organization, 28, 19-25. 
Worchel, S., \& Coutant., D. (2004). It takes two to tango: Relating group identity to individual identity within the framework of group development. In M.B. Brewer \& M. Hewstone, (Eds.), Self and social identity (pp.182-202). Oxford: Blackwell Publishing.

Yadav, M.S. (2010). The decline of conceptual articles and implications for knowledge development. Journal of Marketing, 74, 1-19

Yamin, M., \& Andersson, U. (2011). Subsidiary importance in the MNC: What role does internal embeddedness play? International Business Review, 20, 151-162.

Yoo, J.J., \& Frankwick, G.L. (2012). New product development capabilities and new product performances: Moderating role of organizational climate. Journal of Global Scholars of Marketing Science: Bridging Asia and the World, 22, 83-100.

$\mathrm{Yu}, \mathrm{S}$. (1998-1999). The growth pattern of Samsung electronics. International Studies of Management and Organization, 28, 57-72. 
1

2

3

4

5

6

7

8

9

10

11

12

13

14

15

16

17

18

19

20

21

22

23

24

25

26

27

28

29

30

31

32

33

34

35

36

37

38

39

40

41

42

43

44

45

46

47

48

49

50

51

52

53

54

55

56

57

58

59

60
Figure 1: Conceptual framework outlining how group work and communication are underpinned by the organizational learning concept and result in a high level of customer service.

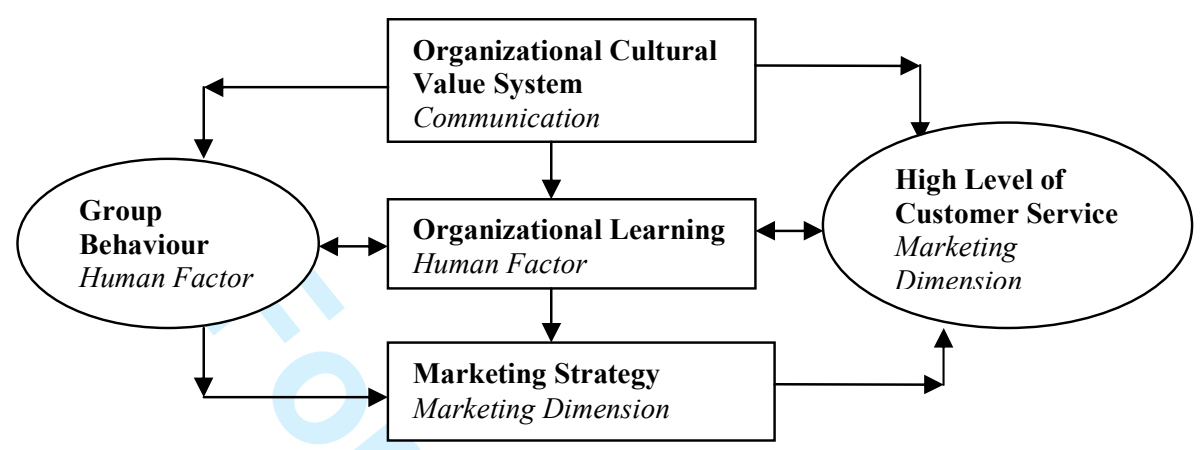


Table 1: The organizational learning and marketing strategy development model deployed in a Korean electronics company.

\begin{tabular}{|c|c|c|c|}
\hline $\begin{array}{l}\text { Strauss and } \\
\text { Corbin's } \\
\text { Paradigm model }\end{array}$ & $\begin{array}{l}\text { Paradigm } \\
\text { model - } \\
\text { chaebol's } \\
\text { approach to } \\
\text { organizational } \\
\text { learning }\end{array}$ & $\begin{array}{l}\text { Chaebol's } \\
\text { organizational } \\
\text { learning model }\end{array}$ & Attributes relating to strategy deployment \\
\hline Causal conditions & $\begin{array}{l}\text { Situational } \\
\text { condition }\end{array}$ & $\begin{array}{l}\text { Government establish } \\
\text { industry strategy. } \\
\text { Meet customers' } \\
\text { needs. }\end{array}$ & $\begin{array}{l}\text { Pay attention to how the state integrates economic } \\
\text { policy with political development. } \\
\text { Industrialization and national growth is planned by } \\
\text { the state. } \\
\text { - } \\
\text { Competitors in the market. }\end{array}$ \\
\hline Phenomenon & $\begin{array}{l}\text { Ethos of the } \\
\text { firm }\end{array}$ & $\begin{array}{l}\text { Achieve its targeted } \\
\text { growth via skilled } \\
\text { staff. } \\
\text { Customer service. }\end{array}$ & $\begin{array}{l}\text { Companies controlled through capital and licensing, } \\
\text { authorization for example. } \\
\text { Maintaining/increasing reputation. } \\
\text { - } \quad \text { Maintain/increasing loyalty. }\end{array}$ \\
\hline Context & The means & $\begin{array}{l}\text { Monitoring and } \\
\text { sharing information. }\end{array}$ & $\begin{array}{l}\text { Identify key government representative(s) and align } \\
\text { strategic focus with industry. } \\
\text { Embrace flexibility. } \\
\text { - } \\
\text { Reduce uncertainty and identify new opportunities to } \\
\text { - } \\
\text { Improve changes in government policy. } \\
\text { Develop knowledge and utilize skills. }\end{array}$ \\
\hline $\begin{array}{l}\text { Intervening } \\
\text { conditions }\end{array}$ & Tools & $\begin{array}{l}\text { Cultural influence. } \\
\text { Relationship } \\
\text { management. }\end{array}$ & $\begin{array}{ll}\text { - } & \text { Controlled through family ties. } \\
\text { - } & \text { Recruitment (e.g. Yon-go and Gong-che). } \\
\text { - } & \text { Maintained through political connections. } \\
\text { - } & \text { Establish acceptable level of trustworthiness and } \\
\text { loyalty. } \\
\text { - }\end{array}$ \\
\hline $\begin{array}{l}\text { Action/interactional } \\
\text { strategies }\end{array}$ & Corollary & $\begin{array}{l}\text { Continual } \\
\text { communication. }\end{array}$ & $\begin{array}{l}\text { - } \\
\text { Pdapt a paternalistic management style. } \\
\text { Perception of the individual's level of skills and } \\
\text { knowledge. } \\
\text { - } \quad \text { Well connected politically. } \\
\text { Understand customers' expected perception. }\end{array}$ \\
\hline \multirow[t]{3}{*}{$\begin{array}{l}\text { Consequences/out- } \\
\text { comes }\end{array}$} & Output 1 & Staff work as a team. & $\begin{array}{ll}- & \text { Team harmony. } \\
\text { - } & \text { Loyalty. } \\
\text { - } & \text { Trustworthy behaviour. } \\
\text { - } & \text { Establish positive relationship with customers. }\end{array}$ \\
\hline & Output 2 & $\begin{array}{l}\text { Managers embrace } \\
\text { diversity for skill } \\
\text { enhancement. }\end{array}$ & $\begin{array}{ll}- & \text { Meritocracy. } \\
- & \text { Fluid and adaptable. }\end{array}$ \\
\hline & Output 3 & $\begin{array}{l}\text { Communication } \\
\text { produces mutual } \\
\text { benefits. }\end{array}$ & Pro-active approach to managing change. \\
\hline
\end{tabular}


Page 37 of 38

Journal of Global Scholars of Marketing Science

$$
\begin{aligned}
& 1 \\
& 2 \\
& 3 \\
& 4 \\
& 5 \\
& 6 \\
& 7 \\
& 8 \\
& 9 \\
& 10 \\
& 11 \\
& 12 \\
& 13 \\
& 14 \\
& 15 \\
& 16 \\
& 17 \\
& 18 \\
& 19 \\
& 20 \\
& 21 \\
& 22 \\
& 23 \\
& 24 \\
& 25 \\
& 26 \\
& 27 \\
& 28 \\
& 29 \\
& 30 \\
& 31 \\
& 32 \\
& 33 \\
& 34 \\
& 35 \\
& 36 \\
& 37 \\
& 38 \\
& 39 \\
& 40 \\
& 41 \\
& 42 \\
& 43 \\
& 40 \\
& 59 \\
& 53 \\
& 46 \\
& 47 \\
& 48 \\
& 59 \\
& 50 \\
& 52 \\
& 5 \\
& \hline
\end{aligned}
$$

Figure 2: The extended and modified conceptual framework outlining how group work and communication are underpinned by the organizational learning concept and result in a high level of customer service.

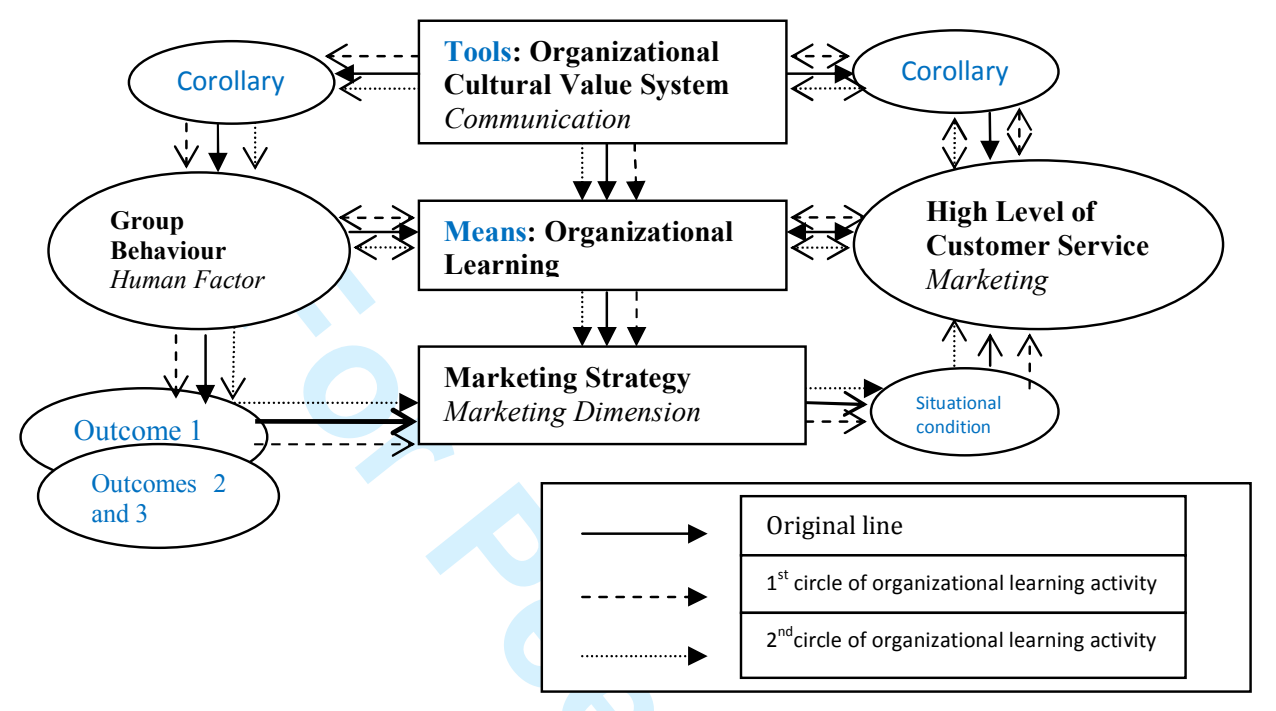

1

URL: http://mc.manuscriptcentral.com/rgam 
Table 2: Environmental characteristics and attributes of Korean companies

\begin{tabular}{|c|c|c|}
\hline \multirow[t]{2}{*}{ Authors } & Environmental characteristics & \multirow[t]{2}{*}{ Korean company attributes } \\
\hline & (External environment) & \\
\hline $\begin{array}{l}\text { Song, 1992; Ungson et al., 1997; Kim \& } \\
\text { Yi, 1998-1999; Shin, 1998-1999; Jeong, } \\
\text { 1999; Lee \& Trim, } 2013 .\end{array}$ & $\begin{array}{l}\text { Country's economic stage of } \\
\text { development. }\end{array}$ & Enterprise stage of development. \\
\hline $\begin{array}{l}\text { Ungson et al., 1997; Kim \& Yi, 1998- } \\
\text { 1999; Yu, 1998-1999. }\end{array}$ & Quality of labour in the market. & $\begin{array}{l}\text { High quality of labour available in the } \\
\text { market (e.g. literacy } 98 \% \text { of the } \\
\text { population; high school - } 80 \% \text { of the } \\
\text { population; } \\
\text { University/college/vocational training } \\
54.6 \% \text { of the population). }\end{array}$ \\
\hline $\begin{array}{l}\text { Ungson et al., 1997; Kim \& Yi, 1998- } \\
\text { 1999; Yu, 1998-1999. }\end{array}$ & Cost of labour in the market. & The wages paid are relatively low. \\
\hline $\begin{array}{l}\text { Song, 1992; Ungson et al., 1997; Jeong, } \\
\text { 1999; Kim \& Yi, 1998-1999; Shin, } \\
\text { 1998-1999; Lee \& Trim, } 2012 .\end{array}$ & $\begin{array}{l}\text { A company's relationship or } \\
\text { association with government. }\end{array}$ & $\begin{array}{l}\text { Integrated within the state } \\
\text { development process. }\end{array}$ \\
\hline & (Internal environment) & \\
\hline Song, 1992; Shin, 1998-1999. & Company structure. & $\begin{array}{l}\text { No clear distinction/division between } \\
\text { top manager(s) and the founder/owner- } \\
\text { manager. }\end{array}$ \\
\hline Kim \& Yi, 1998-1999. & \multirow{2}{*}{ Role of the manager. } & Facilitator. \\
\hline Kim \& Yi, 1998-1999; Shin, 1998-1999. & & Planner. \\
\hline $\begin{array}{l}\text { Kim \& Yi, 1998-1999; Lee, 1998-1999; } \\
\text { Jeong, } 1999 .\end{array}$ & Control. & $\begin{array}{l}\text { Highly centralized, but relatively less } \\
\text { formalized and is influenced by top } \\
\text { management. }\end{array}$ \\
\hline $\begin{array}{l}\text { Ungson et al.,1997; Kim \& Yi, 1998- } \\
\text { 1999; Lee, 1998-1999; Whang, 1998- } \\
\text { 1999; Jeong, 1999. }\end{array}$ & $\begin{array}{l}\text { Recruitment of new members of } \\
\text { staff. }\end{array}$ & $\begin{array}{l}\text { Yon-go and/or Gong-che - (extension } \\
\text { of Yon-go - adapting western } \\
\text { managerial approaches to select the } \\
\text { best people as possible via (individual) } \\
\text { connections). }\end{array}$ \\
\hline $\begin{array}{l}\text { Ungson et al.,1997; Chen, 1995; Kim, } \\
\text { 1997; Kim \& Yi, 1998-1999; Shin, } \\
\text { 1998-1999; Woo in Kim \&Yi, 1998- } \\
\text { 1999; Lee \& Trim, } 2013 .\end{array}$ & Leadership style. & Strongly paternalistic. \\
\hline $\begin{array}{l}\text { Ungson et al., 1997; Chen, 1995; Kim, } \\
\text { 1997; Kim \& Yi, 1998-1999; Shin, } \\
\text { 1998-1999; Woo in Kim \& Yi, 1998- } \\
\text { 1999; Lee \& Trim, } 2013 .\end{array}$ & $\begin{array}{l}\text { Influence of the national cultural } \\
\text { value system on the } \\
\text { organization's value system. }\end{array}$ & Direct and strong. \\
\hline Ungson et al., 1997. & $\begin{array}{l}\text { Expected employee(s) behaviour } \\
\text { [toward their task/ job } \\
\text { description]. }\end{array}$ & Responsible; accountable. \\
\hline
\end{tabular}

